\title{
EFFICIENCY OF DAIRY CATTLE-BREEDING IN BULGARIA
}

\author{
Hrabrin Bachev, Dimitar Nikolov, Ivanka Yanakieva, Teodor Radev \\ Institute of Agricultural Economics, \\ 125 Tzarigradsko shosse Blvd, Blok 1, 1113 Sofia, Bulgaria \\ radev1974@abv.bg
}

\begin{abstract}
The high degree of uncertainty is a feature of modern business environment where firms, especially farms face with new challenges. In that situation farms should improve their management which is a permanent process. The main characteristics of farms at the managerial point is that the farmers make decision according to the rational combination of resources (land, labour and capital) and make production. On the farm various activities which concern production of wheat, corn, potatoes, tomatoes, milk and meat can be implemented. These activities are called farm productions. The market of farm products functions nearly to the conditions of perfect competition. This limits the farmer's decisions about production only with the type, place, time and amount which have to be produced. The farmer carries out two roles, he is both a grower and a manager. In crops the farmer is responsible for seeding, cultivating and irrigating and the pests control. In livestock the farmer breeds animals and keeps them healthy. The other farmer's role as a manager is important for the good health of the farm. While agriculture requires agronomic and zootechnical knowledge, management can be defined as a process of making decisions. The farmer makes a choice between different crops and animals, according to available resources and market conditions.
\end{abstract}

Key words: farmer's roles; farm management; gross margin; efficiency

\section{ЕФИКАСНОСТА НА МЛЕЧНОТО ГОВЕДАРСТВО ВО БУГАРИЈА}

Високиот степен на неизвесност е карактеристика на модерниот бизнис, каде фирмите, а особено фармите, се соочуваат со нови предизвици. Во таа ситуација фармите би требало да го унапредат својот менаџмент, што претставува перманентен процес. Најважна карактеристика на фармите од аспект на менаџментот е фармерите да донесуваат одлуки во согласност со рационалната комбинација на ресурсите (земјиште, труд и капитал) и оствареното производство. На фармата можат да бидат применети разновидни активности кои се однесуваат на производството на пченица, пченка, компири, домати, млеко, месо итн. Овие активности се наречени фармско производство. Пазарот на фармските производи функционира приближно на условите на перфектна конкуренција. Ова ги ограничува одлуките на фармерот во врска со производството само во поглед на типот, местото, времето и количеството кое треба да го произведат. Фармерот се јавува во две улоги, тој е и одгледувач и менаџер. Во растителното производство фармерот е одговорен за сеењето, култивирањето, наводнувањето и за контрола на штетниците. Во сточарството фармерот ги одгледува животните и го одржува нивното здравје. Улогата на фармерот како менаџер е важна за доброто здравје на фармата. Додека земјоделството бара агрономско и зоотехничко знаење, менаџментот може да биде дефиниран како процес на донесување одлуки. Фармерот прави избор меѓу различни жетви и животни, во согласност со расположливите ресурси и условите на пазарот.

Клучни зборови: улоги на фармерот; менаџирање на фарма; бруто-вишок; ефикасност

\section{INTRODUCTION}

Every farm is established on the land, which involves farm activities in purpose of producing agricultural products and it provides income for the farmer's household. The farm has its agricultural infrastructure such as drillings, irrigation canals, livestock houses, barns and a family's house. The farm also covers plants, animals and other resources, which are necessary for agricultural 
productions. Some farmers' activities are ploughing, planting, breeding and combination of them. The object of management is common feature of farms. The concept of a farm is the core of its management.

The high degree of uncertainty is a typical feature of modern business environment where firms, especially farms face new challenges. In that situation farms should improve their management which is a permanent process. The main characteristics of farms at the managerial point are the farmers to make decision according to the rational combination of resources (land, labour and capital) and to make production. On the farm various activities which concern production of wheat, corn, potatoes, tomatoes, milk and meat can be implemented. These activities are called farm productions.

Farms usually cover several productions. They need inputs and delivery outputs. Some of the outputs can be used as inputs to other productions. Final products of farms go to market.

The market possesses some important features, which influence farms. They are expressed as follows:

- products are usually homogeneous (raw material), so the farmer can't distinguish his own products from the products of others farmers;

- a great number of producers sell products and no one of them can influence the market;

- the little relative share of the producer is the obstacle to set his own price. The price is the result of interaction between the aggregate supply and the aggregate demand or the farmer takes the price;

- it is easy to enter and leave the sector, because of relative lower capital investment than other sectors.

The market of farm products functions as in the conditions of perfect competition. This limits the farmer's decision about production of the type, place, time and the amount to be produced.

The farmer carries out two roles, he is both a grower and a manager. In crops the farmer is responsible for seeding, cultivating, irrigating and pests control. In livestock the farmer breeds animals and keeps them healthy.

The other farmer's role as a manager is important for good health of the farm. While agriculture requires agronomic and zootechnical knowledge, management can be defined as a process of making decisions. The farmer makes a choice be- tween different crops and animals, according to the available resources and market conditions. The farmer also decides how to organize production or what technology to be applied.

The aim of the report is to present the Gross margin as a method for management of farms, by discussing its special features and demonstrating application in a certain sector.

\section{METHODOLOGY}

Special features of agricultural products assume to put into practice good management methods. They can help farmers to make their decisions. The method of the Gross margin is one of them, as an economical method. The method was used widely in Great Britain during $60^{\text {th }}$ years of last century. It was popularized for analyzing and planning in agriculture.

The essence of the method is calculation of the gross margin value. It is a difference between the total income and the variable cost for the whole farm or a certain crop/animal. Jay Ebben [1] assigns the method as an appropriate tool for determining break even point and management profit beyond this point in small and new enterprises. The author considers the gross margin method suitable when the product price is low, but the variable costs are high. Agriculture often faces this situation.

The consulting organization in primary industries of South Wales Australia (NSW DPI) [2], assigns calculating the gross margin value as the first step of developing the farm plan and budget. In this way profitability of different productions can be compared and it is useful to make a decision in farming. This organization recommends the results of farming to be estimated through the gross margin value and the obtained value to be compared with the benchmark.

Chris Firth [3] uses the gross margin value to provide a comparative economic analysis in organic farming to conventional production. In fact he extends the method measuring different technologies.

D. Nikolov [4] assigns the gross margin as a good tool in analyzing and assessing agricultural production.

In the European Union classification of holdings is based on their type and economic size, two elements which in turn are based on the gross mar- 
gins of the various types of agricultural production.

The gross margin is also used under the name of standard difference by the Bulgarian Ministry of Agriculture and the total profit by N. Nikolov [5], but the meaning is the same and there is no difference in calculating the values.

The advantages of the gross margin analysis include the following:

- The information required is simple and can easily be collected by the field personnel.

- The analysis is easy to complete requiring only a calculator although it can be done even more easily on a computer spreadsheet.

- The results are easy for farmers, extension workers, and policy makers to understand.

- The results can be very useful in helping farmers decide whether or not to adopt the technology or farm enterprise. Extension workers decide whether or not to encourage other farmers to adopt the technology or farm enterprise. Policy makers and development specialists make more appropriate decisions relating to the design of development projects.

The method is easy to apply because it doesn't need specific knowledge or skills. Nevertheless we will discuss some questions about calculating the gross margin value.

\section{Steps in the gross margin analysis}

There are a number of steps involved in setting up a gross margin for a specific technology relating to a farm enterprise. An example of specific steps in setting up the gross margin for each calculation is presented below:

- calculate an average yield expected for the crop with the technology to be applied. Where the product has not been produced before this will have to be based on information from other farmers or the advice of national agricultural research or extension services. However, as such services tend to farm in ideal conditions not replicated by small farmers it would be useful to reduce expected yields to take this into account;

- calculate the expected gross return, which is the expected production multiplied by the price at the farm gate. Take the information on prices available from the market information service and deduct all marketing costs from the farm gate to the market to which the prices refer;
- calculate seed, fertilizer and pesticide requirements per hectare or for the crop area and work out the total cost of these at the farm gate. It is also necessary to add costs of transport and other costs from the dealer to the farm;

- calculate costs of irrigation water and machinery services required for the relevant area, if these services are obtained commercially;

- estimate costs (other than labour) of irrigation and machinery services if the farmer provides these;

- calculate cost of fixed investments required solely for this crop, e.g. plastic tunnels for horticulture production, dividing the cost of the investment by the number of crops (or years when there is just one crop a year) the investment is expected to be used for;

- on the basis of research/extension service advice or other information, estimate the number of persons/days required for land preparation, sowing, weeding and other production activities such as harvesting, cleaning, grading and packing. Multiply the number of days by the cost of labour;

- where family labour is used multiply the number of days by the opportunity cost, i.e. the daily wage that members of the family could earn if they weren't working on the farm;

- deduct the rent paid for the area of land used or the bank interest paid if the land is being purchased. Where the land is fully owned by the farmer and there is a possibility of renting it out then the opportunity cost of that land (i.e. the potential rent) should be deducted;

- deduct any taxes on the land (but not on the products) and any interest paid on the land or inputs;

- apportion any other farm costs not included above according to the land area for the crop as a percentage of the total farm land area, divided by the number of crops annually;

- subtract total costs from total revenues to get the gross margin for the crop per hectare or per parcel of land it is intended to use.

\section{Challenges and good practices}

There are a number of issues that need to be considered when undertaking a gross margin analysis. Some improve the potential validity of the results while others increase its potential use in comparing the results with results elsewhere and help in assessing appropriate plans for the future. 
Some of the major issues are considered in the following paragraphs - they are not given in any particular order of priority.

\section{Time period to consider}

It is very important to use the same time period for all enterprises and technologies if one intends to compare the gross margins of different enterprises or technologies.

What time period should be used for calculating the gross margin? The period usually used is one production cycle. This varies for different enterprises but a compromise commonly used is a year. For example, cereal and legume crops differ somewhat in the length of their production cycles but in many drier parts of the world only one production cycle is possible for each in a year so a year is a convenient period to use.

If in comparing two different enterprises, the production cycle of one enterprise (e.g., enterprise A) is much shorter than another (e.g., enterprise B), it might be better to pick a time period that allows for one production cycle of $\mathrm{B}$ to be completed and compare it with, for example, two production cycles of enterprise A.

\section{Prices of products and costs of inputs}

The gross margin analysis requires output and inputs to be expressed in terms of a common denominator, that is, a monetary unit. The issue becomes one of deciding whether farm gate (i.e. what it would cost at the farm site itself) or market (i.e. what you actually paid for it) price or cost should be used. The farm gate price or cost involves no marketing cost component. If a product is sold on the market away from the farm, any marketing costs (e.g., the cost of transporting it to the market, the time involved) need to be subtracted from the market price that was received to obtain the farm gate price. If the input was purchased away from the farm, then to get the farm gate cost, any costs involved in getting it to the farm (e.g., transport cost, time involved) need to be subtracted. [Time involved in transporting products to and from the market, and in identifying buyers and sellers can be considerable. Therefore it may be necessary to put some sort of value on that time.]

Either farm gate or market prices can be used. However, it is important in reporting the results of the gross margin analysis to document what prices were used.

\section{Valuing by-products}

Enterprises are usually implemented with the aim of producing a single product. However, there often are by-products that are valued by farmers and their families. An example is wheat where not only the grain is produced for the market but also the straw can be used in the livestock production. If such by-products have a potential market value then their production and value should be estimated and included in the calculation of the gross income.

\section{Variable inputs lasting more than one production cycle}

The amounts used for the gross margins analysis must be adjusted when some inputs or outputs last more than one a production cycle. Two examples are planting alfalfa, which can be cut for hay for more than a production cycle, and the purchase of plastic tunnels to produce vegetables during the off-season which also last more than one production cycle. In both cases it would be incorrect to allocate all the costs to the first production cycle. Instead the costs per year need to be calculated with the help of the following formula:

$$
A=\frac{(C-S)}{L}
$$

where:

$A$ - annual cost,

$C$ - initial cost,

$S$ - salvage value (an estimate of what you could get for it at the end of its useful life),

$L$ - estimated useful life (in years).

\section{Imputing variable costs using opportunity costs}

Much of the labour and other inputs (e.g. seeds) on small farms come from family sources. To make valid comparisons between different enterprises or different technologies relating to the same farm enterprise, it is necessary to impute, that is estimate, a cost for these family resources. For family labour, this is done through valuing it at what it would cost to hire such labour. Essentially in doing this we are using the opportunity cost of labour. This could vary according to the season or person providing the labour (e.g. male, female, 
youth). For seeds or other variable inputs, the normal practice is to value them at what it would cost to obtain from the next most likely source of supply (neighbour, local trader, etc.).

\section{Interest charges}

If in order to adopt a particular enterprise or technology, money is borrowed, the interest to be paid on that loan is a variable cost. In such cases, the interest charge that would be imputed could be approximately calculated as follows:

$$
I=\frac{i \times V}{2}
$$

where:

$I$ - annual interest charge,

$i$ - the relevant annual interest rate, that is, an estimate of what the rate would be if you borrowed the money,

$V$ - the actual variable costs paid out.

\section{Calculating gross margins per unit of family labour}

When comparing technologies or enterprises in terms of a gross margin per unit of family labour, the gross margins should be calculated excluding the imputed cost for family labour inputs. The gross margin that is obtained with family labour costs excluded is then divided by the number of units of family labour used in that enterprise or technology.

If there is interest in calculating the gross margin per unit of labour only for a labour bottleneck period (e.g. weeding period), then the gross margin should be calculated including the imputed family labour cost outside the bottleneck period. The obtained gross margin is then divided by the number of units of the family labour used during the bottleneck period.

\section{RESULTS}

The method is applied to 8 dairy farms. The farms are divided in two groups according to the amount of expenditures - intensive and extensive. They also correspond to no-pasture and pasture animal breeding. Two production systems are compared on data from 2007. The used data was obtained by survey. The data about the intensive system (no-pasture) is a part of GTG project "Improvement of Milk Quality in Bulgaria” [6].
Expenditures of farms using the intensive system are two times more than expenditures of extensive one. The amount is $1646 €$. The higher value is relevant to answer the need of animals with fodder. It is represented by a high share of feed from variable costs (see Table 1). The share of feed from variable costs is $80 \%$ for the intensive system, while the share for the extensive system is only $63 \%$. Converting these percentages into value shows that the cost of feed of the extensive system is greater than the total variable cost of the extensive system (approximately $50 \%$ ). In that way the intensive system reached milk yield of $58831 /$ cow or 3 times more than the extensive system (1 825 1/cow). Obviously each paid monetary unit has different contribution to the milk yield in the two systems. It can be said that extension of expenditures is advisable.

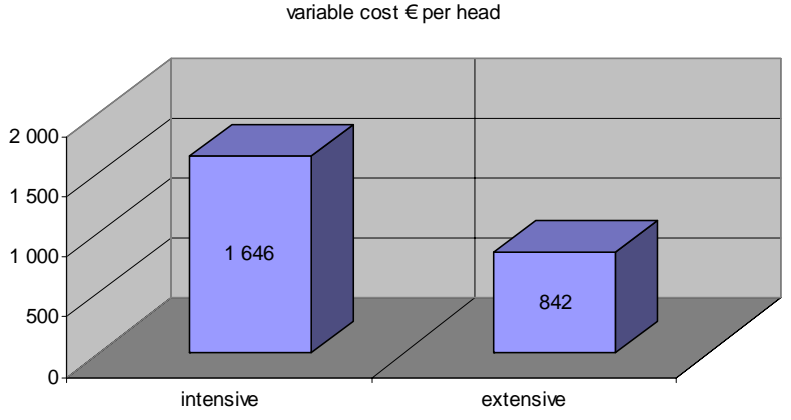

Fig. 1. Variable cost per head (yearly in euro)

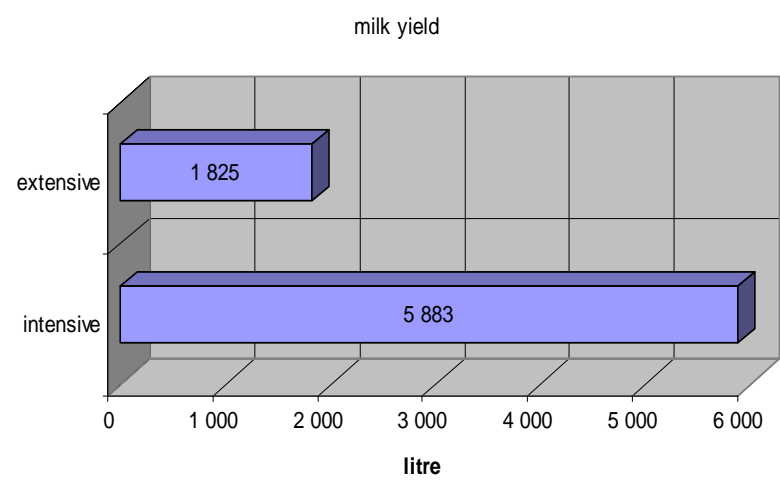

Fig. 2. Milk yield yearly

The results from the research are about calculating the gross margin (GM) per head and per 1 litre milk. GM per head of the intensive system is $896 €$, while the extensive system obtained only $131 €$. Recognize that big difference should be pointed that the intensive system has the larger extent of the fixed cost. Despite all the intensive system is more profitable than the extensive one. 
The obtained high level is explained by both reached high milk yield and a high milk price (see Table 1). In that way farms with the extensive system not only compensate their high expenditures but realize additional income. High milk yield was yet discussed. But the milk price should be considered as an element partly controlled by the farmer. The price is fixed as a result of the action of many factors. In the observed farms the main factors lead to fix a high milk price and large delivery amount and guarantee high and stable quality of milk which are result of high expenditures of the intensive system. Obviously there are benefits in different fields. Based on combining these benefits farms applied the intensive system and obtained much higher gross margin per head than farms that applied the extensive system.

Table 1

\section{Production cost and GM analysis}

\begin{tabular}{|c|c|c|c|c|c|c|c|c|c|c|c|}
\hline Farm code & $\begin{array}{c}\text { Pazarjik } 1 \\
\text { Intensive }\end{array}$ & $\begin{array}{c}\text { Pazarjik } 2 \\
\text { Intensive }\end{array}$ & $\begin{array}{c}\text { Pazarjik } 4 \\
\text { Intensive }\end{array}$ & $\begin{array}{c}\text { Pazarjik } 3 \\
\text { Intensive }\end{array}$ & $\begin{array}{c}\text { Sitovo } 1 \\
\text { Extensive }\end{array}$ & $\begin{array}{c}\text { Sitovo } 2 \\
\text { Extensive }\end{array}$ & $\begin{array}{c}\text { Bolyarovo } 5 \\
\text { Extensive }\end{array}$ & $\begin{array}{l}\text { Yambol } 6 \\
\text { Extensive }\end{array}$ & $\begin{array}{l}\text { Average } \\
\text { Intensive }\end{array}$ & $\begin{array}{l}\text { Average } \\
\text { Extensive }\end{array}$ & $\begin{array}{c}\text { Average } \\
\text { Total }\end{array}$ \\
\hline Cow number & 32 & 110 & 30 & 64 & 40 & 40 & 20 & 120 & 59 & 55 & 57 \\
\hline Milk yield $1 /$ cow & 4531 & 8500 & 5000 & 5500 & 1800 & 2100 & 1500 & 1900 & 5883 & 1825 & 3854 \\
\hline Produced milk 1 & 145000 & 935000 & 150000 & 352000 & 72000 & 84000 & 30000 & 228000 & 395500 & 103500 & 249500 \\
\hline Milk price $€ / 1$ & 0.33 & 0.36 & 0.35 & 0.35 & 0.25 & 0.25 & 0.25 & 0.28 & 0.35 & 0.26 & 0.30 \\
\hline Total income $€$ & 59170 & 384375 & 61375 & 142100 & 32000 & 45500 & 10000 & 131616 & 161755 & 54779 & 108267 \\
\hline Income from milk \% & $80 \%$ & $89 \%$ & $87 \%$ & $87 \%$ & $56 \%$ & $46 \%$ & $75 \%$ & $74 \%$ & $86 \%$ & $63 \%$ & $74 \%$ \\
\hline Subsidies \% & $17 \%$ & $10 \%$ & $13 \%$ & $13 \%$ & $19 \%$ & $16 \%$ & no subsidies & $8 \%$ & $13 \%$ & $14 \%$ & $13.5 \%$ \\
\hline Share of feed from V cost & $79 \%$ & $79 \%$ & $81 \%$ & $81 \%$ & $69 \%$ & $79 \%$ & $40 \%$ & $64 \%$ & $80 \%$ & $63 \%$ & $72 \%$ \\
\hline Variable cost $€$ & 29763 & 233099 & 46844 & 90589 & 27370 & 40070 & 8200 & 109542 & 100073 & 46296 & 73184 \\
\hline Variable cost $€$ per 1 & 0.41 & 0.5 & 0.62 & 0.51 & 0.76 & 0.95 & 0.55 & 0.96 & 0.51 & 0.81 & 0.66 \\
\hline $\mathrm{Gm} €$ & 29407 & 151285 & 14531 & 51511 & 4630 & 5430 & 1800 & 22074 & 61682 & 8483 & 35083 \\
\hline GM $€$ per head & 919 & 1375 & 484 & 805 & 116 & 136 & 90 & 184 & 896 & 131 & 514 \\
\hline GM $€$ per 1 & 0.20 & 0.16 & 0.10 & 0.15 & 0.07 & 0.07 & 0.06 & 0.10 & 0.15 & 0.07 & 0.11 \\
\hline Efficiency with subsidies & $50 \%$ & $39 \%$ & $24 \%$ & $36 \%$ & $14 \%$ & $12 \%$ & - & $17 \%$ & $38 \%$ & $15 \%$ & $32 \%$ \\
\hline $\begin{array}{l}\text { Efficiency without } \\
\text { subsidies }\end{array}$ & $39 \%$ & $33 \%$ & $12 \%$ & $27 \%$ & $-6 \%$ & $-5 \%$ & $18 \%$ & $10 \%$ & $29 \%$ & $2 \%$ & $28 \%$ \\
\hline
\end{tabular}

The other important index is the gross margin per 1 litre milk. Farms with the intensive production system obtained value 2 times higher than the extensive system. The value is $0.15 € / 1$. The main reason for that situation is the achieved better level of expenditures per litre.

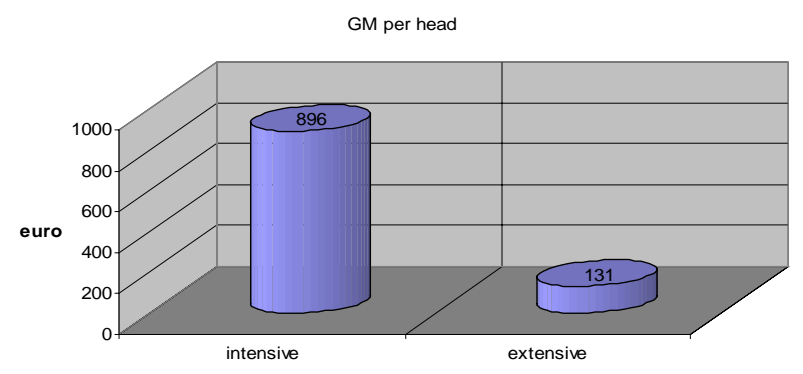

Fig. 3. Gross margin per head
In the intensive system the variable cost per litre is $0.26 € / 1$, while in the extensive system the value is greater $-0.40 € / 1$. The result shows that the intensive system achieved better productivity per $1 €$ expenditure. It is an important premise to obtain a high gross margin per litre milk. Comparing expenditures per litre to the milk price it shows that there is a positive difference in the intensive system, but the extensive system has a negative difference. It creates a good opportunity for achievement of a high gross margin per litre milk and a total gross margin in farms which applied the intensive system. Obviously farms which applied the extensive system face the problem on that field, because their expenditures are higher than the milk price. Therefore by-products and subsidies are very important factors in farms which ap- 
plied the extensive system to eliminate the negative difference.

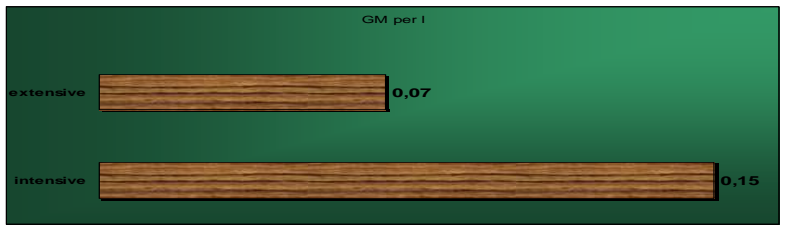

Fig. 4. Gross margin per 1 litre milk

Based on data from the exploration an effectiveness of the production system is accounted, as regard between the value of the gross margin for entire farms and their overall income. The relation is calculated with and without subsidies. The results show that the intensive production system is more efficient in comparison with the extensive one in the two cases. It is shown that the subsidies ape with a relatively larger degree of significance of achieving higher potency in the extensive systems of the economy activity. A main factor is the short milk yield with the extensive production that makes high spending of a 1 litre of milk. Everything that gives a foundation for the role of subsidies in those farms is considered as dual. On one hand they give an opportunity to farms to continue their activity, but on the other hand they have a deterrent effect as well. The subsidies do not make farmers pass to new production systems, because their production efficiency is in a low degree of risk. The intensive production is highly efficient, but the risk is much higher due to the required resources.

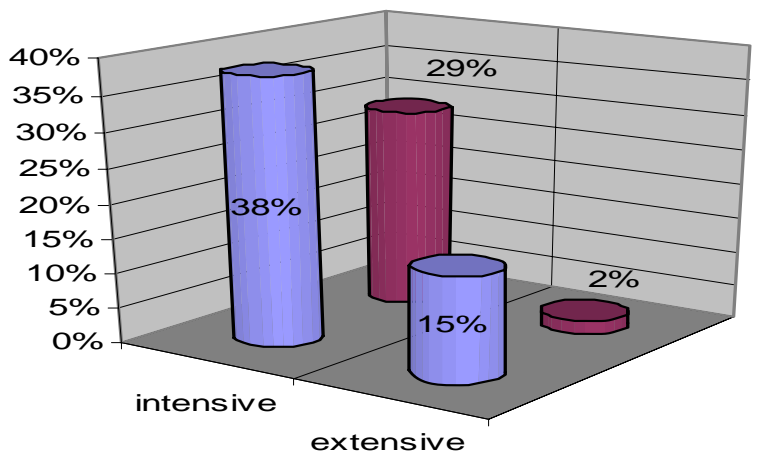

Fig. 5. Efficiency of production

$\square$ efficiency with subsidies, $\square$ efficiency without subsidies

\section{CONCLUSIONS}

Main conclusions of the research are:

- The gross margin can be used as a tool measuring efficiency of production.

- Using more resources increased the milk productivity what is the main reason these farms to record a higher value of the gross margin per head and per litre.

- The high intensive production system is more efficient than the extensive one.

- Perceived subsidies by farms don't stimulate them to initiate the intensive production system.

In conclusion it can be generalized that the method Gross margin possesses a rich analytical ability. Calculating on the national and regional level the gross margin can provide a good support to improve the management of farms. It needs to create a data-base on production and year, and be available for everyone concerned in agriculture.

\section{REFERENCES}

[1] http:/www.inc.com/resources/articles/20041201/grossmar gin.html

[2] http://www.agric.nsw.gov.au/agriculture/farmbusiness/budget /about /intro

[3] http://www.organic.aber.ac.uk/library/Gross $\% 20$ and $\% 20$ net $\% 20$ margins $\% 20$ for $\% 20$ economic $\% 20$ analysis.pdf

[4] Nikolov, D., Hr. Bachev, Iv. Yanakieva, 2008: How to manage money in efficiency way in agriculture. Energy print,

[5] Nikolov, N., 1997: Design production structure of farm. Stopanstvo.

[6] Nikolov, D.: Gross margin calculation in Bulgarian dairy sector (sample from Plovdiv and Pazardzhik regions). 